Historic, archived document

Do not assume content reflects current scientific knowledge, policies, or practices. 

PACIFIC NORTHWEST FOREST AND RANGE EXPERIMENT STATION - PORTLAND, OREGON FOREST SERVICE

U.S. DEPARTMENT OF AGRICULTURE

Ressive 99

i76250 (3),

1970

USDA FOREST SSERVICE RESEARCH PAPER PNW $=93$

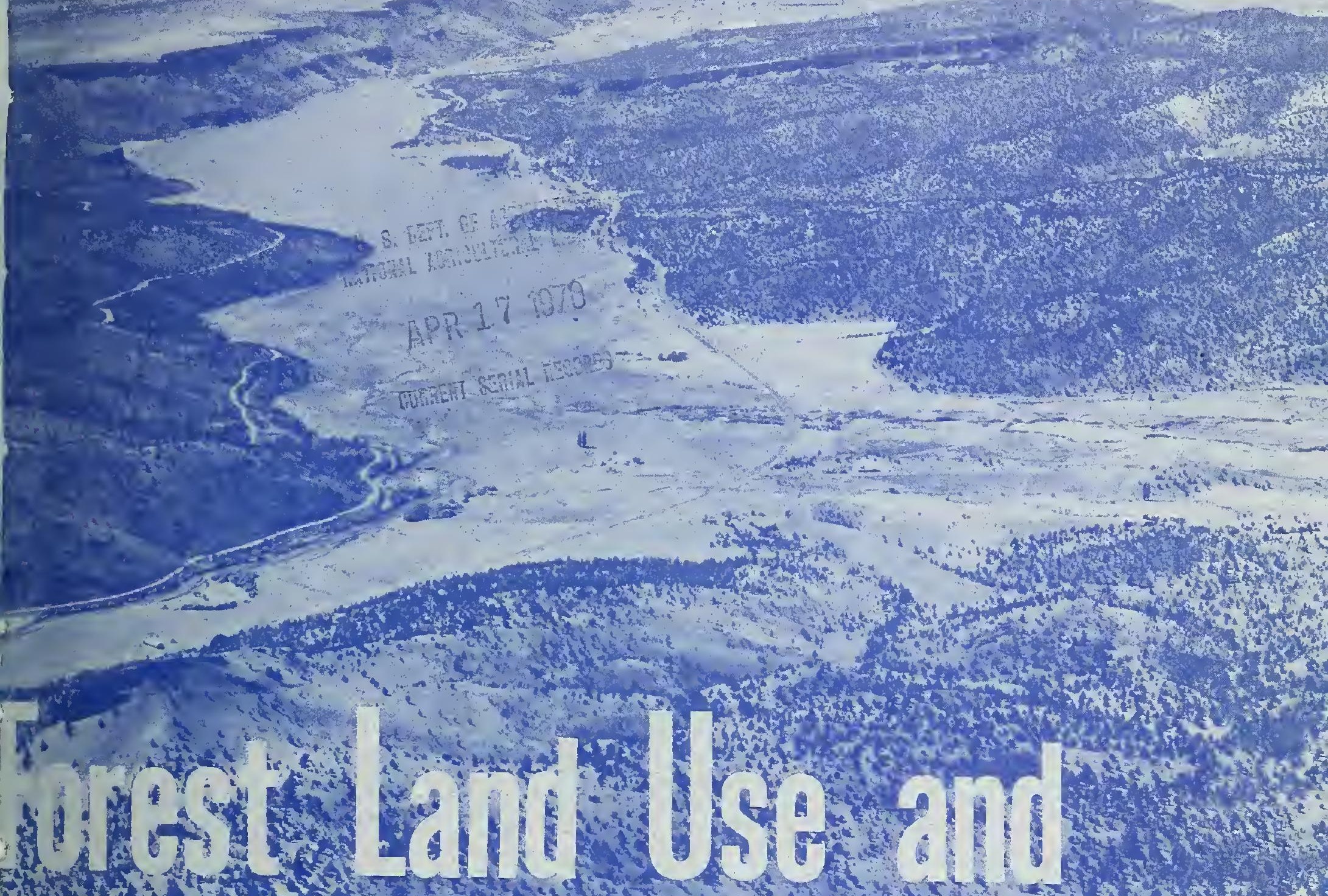

W

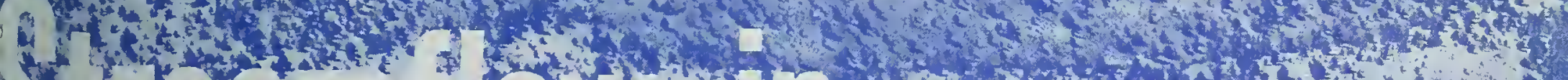
t)

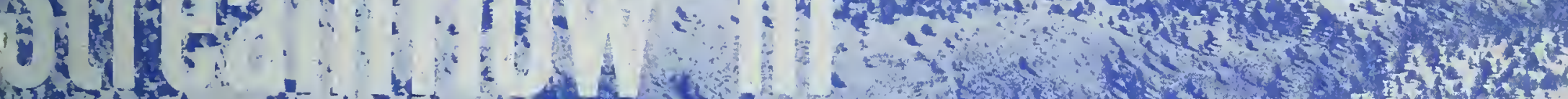

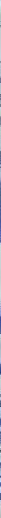

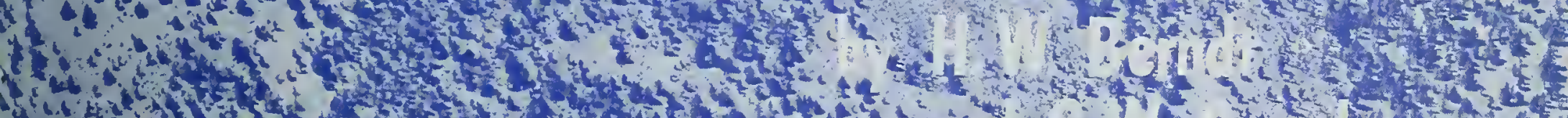

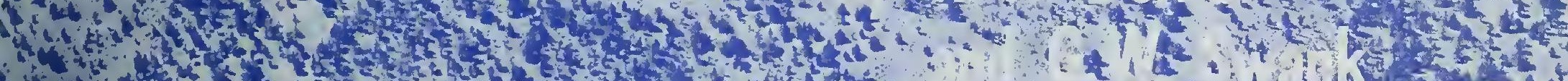

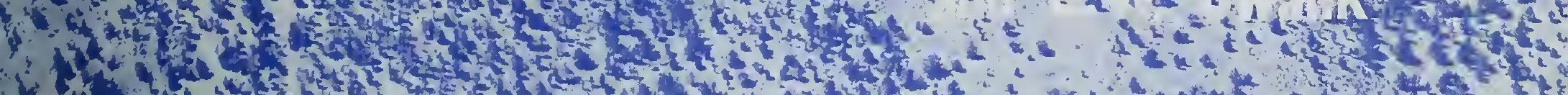

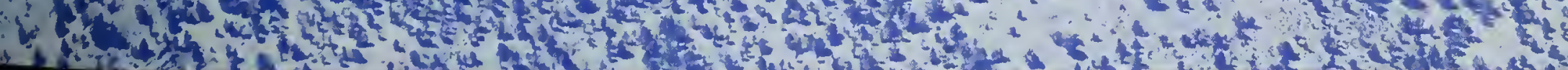


CONTENTS

THE SITUATION $\ldots \ldots \ldots \ldots \ldots \ldots \ldots \ldots \ldots \ldots \ldots \ldots \ldots \ldots \ldots$

WHAT IS UNDERSTOOD . . . . . . . . . . . . . . . . . . . 2

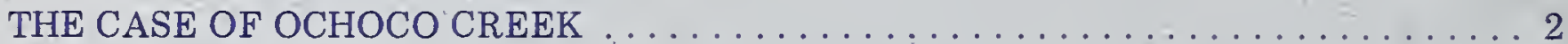

Study Area . . . . . . . . . . . . . . . . . . . . . . . . . . 2

Land Use History $\ldots \ldots \ldots \ldots \ldots \ldots \ldots \ldots \ldots \ldots \ldots \ldots \ldots \ldots \ldots \ldots$

Hydrologic Relations . ........................... 9

Precipitation-Runoff Relations . . . . . . . . . . . . . . . . . 10

Double-Mass Analysis . . . . . . . . . . . . . . . . . . . . 12

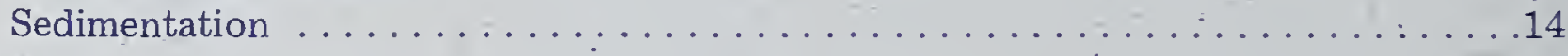

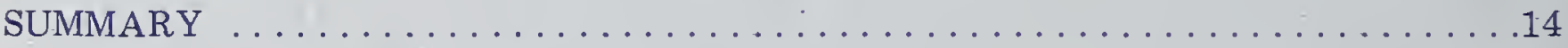

LITERATURE CITED . . . . . . . . . . . . . . . . . . . . . . 15

H. W. Berndt is a research forester for Water Yield Improvement and Erosion Reduction, East-side Cascades, Wenatchee, Wash.

G. W. Swank is a forester with Division of Watershed Management, Region 6, Forest Service, Portland, Oreg. 


\section{THE SITUATION}

As man's awareness and concern for his environment increase, the forest becomes more recognizable as a storehouse of vital renewable resources - water, wood, forage, recreation, and wildlife habitat. At the same time, in considering man's dependence on his environment, the need to manage these resources by the multiple use principle - in combinations that will best meet the needs of all the people - becomes more apparent. But the growing number of planning factors imposed by rapid change makes multiple use management increasingly complex. Now, more than at any previous time in conservation history, we need to understand how resources of the forest are influenced by planned management for given objectives. This paper considers the broad spectrum of management activities and the water-yielding characteristics of a small basin in central Oregon.

Perhaps nowhere in this rapidly changing Nation is change more readily apparent than in the Pacific Northwest. The situation is exemplified by Oregon's population which has spiraled from only 13,000 permanent settlers in 1850 to approximately $2,000,000$ at present. Though half the present population lives in or near 20 principal commercial or industrial centers, and large volumes of water are withdrawn for domestic, industrial, and power production users, irrigation is the greatest consumptive use of water in Oregon (13). From simple diversions by early settlers, irrigation agriculture now extends to more than $1,500,000$ acres. A recent report by the Oregon State Water Resources Board (12) projects a population of $9,000,000$ requiring irrigation of $13,700,000$ acres 100 years from now.

In response to changes that have either taken place or are projected for the future, two trends are of special significance to forest land managers. These are:

1. Demands for water supplies to meet needs are increasing.

2. Demands for use and occupancy of forest lands for the other resources wood, forage, recreation, and wildlife habitat - are also increasing.

Both trends are due to the same mounting pressures - expanding population and improving technology. Fortunately, through increasing general knowledge of the influence of land and vegetation treatments on hydrologic performance, we are beginning to understand that these increasing demands are not necessarily conflicting. Rather, there is an interacting character of good resource management which can be of benefit to watershed objectives. Except where prohibited by certain institutional arrangements for land management, such as National Parks and wilderness areas, management practices applied to other forest resources can gain reinforcement from their effect on water yield. This concept is reflected in recent activity of the U.S. Forest Service in bringing management to bear upon improvement of water yields on lands tributary to a water-short area (17). 


\section{WHAT IS UNDERSTOOD}

General knowledge that vegetation and vegetation management can have a profound influence on streamflow has existed in this country for more than half a century. The earliest study of manipulation of forest vegetation in the United States was the Wagon Wheel Gap experiment begun in Colorado in 1910. In this joint Forest Service-Weather Bureau study, all vegetation was cut, windrowed, and burned on a 200-acre watershed in the headwaters of the Rio Grande River. Then a natural cover of aspen sprouts, grasses, and herbaceous plants was allowed to establish. During 7 posttreatment years, an annual increase of 0.96 inch, or 16 percent of the pretreatment yield, was attributed to removal of vegetation. Most of the increase was accounted for during the spring peak period (2).

A number of tests of forest treatment effects on water yields have been made since the Wagon Wheel Gap study designed to consider variations imposed by differing climate, soils, and vegetative types. These studies, ranging from North Carolina (10) and West Virginia (14) to Colorado (7) and California (15), have yielded the general result that streamflow increases when forest density is decreased. Also, this effect is soon followed by a trend toward original or pretreatment flow values if regrowth is allowed (11) (9). Bates (1), a pioneer in watershed management, likely had the results of his Wagon Wheel Gap study in mind when he wrote, in part:

Foresters, again and again, have pointed
out the probability that a watershed
bare of vegetation is capable of yielding
a larger total quantity of water than the
same watershed if covered with a forest,
and the denser and more luxuriant the
vegetation, the greater the loss of water
to the watershed. This is a biological
phenomenon no longer in need of
proof.

Most investigators, however, see the role of forest vegetation as a paradox. Although there is evidence that forest stands can be modified to favor water yield, vegetation also plays a primary role in site stability and maintenance of water quality. Manipulations to reduce onsite water use should be applied only within limits which do not jeopardize the protective function.
Although studies of the relations between vegetation and water yields have provided intriguing prospects for resource management, there is feeling that the foundation is inadequate for widespread application (4). The scale of the tests has necessarily been limited, and not all regional variations have been touched upon. Broader scale tests or operational demonstrations on the effects of cover manipulation on water yield are needed.

\section{THE CASE OF OCHOCO CREEK}

In order to fix vegetation-streamflow relations on forest lands tributary to water-short areas of Washington and Oregon east of the Cascade Range, a number of experiments are being undertaken. Pending completion of these studies, it is possible to gain some insight on the effects of forest management activities by using available hydrologic data and forest use records. This case study has been made in order to evaluate the hydrologic performance of Ochoco Creek above Ochoco Reservoir (cover photo) in central Oregon in light of the use history of forested lands comprising the bulk of drainage area.

\section{Study Area}

Total drainage area tributary to Ochoco Reservoir, 6 miles east of Prineville, Oreg., is about 295 square miles, or 189,000 acres (see frontispiece). Elevations range from 3,100 feet at the reservoir to nearly 7,000 feet at the headwaters. Mean elevation is 4,600 feet. Generally, topography is gentle (fig. 1), with some rugged terrain at the uppermost reaches. Landscape features are strongly influenced by geologic formations present. A deeply fractured Clarno Formation, considered late Eocene or early Oligocene in age and lacustrine fluviatile in origin, predominates. The eastern or upper portion of the drainage is covered by the younger lavas of the Columbia River Formation. mid-Miocene fissure flows of fine-grained basalts, and andesites. A mantle of volcanic ash or loess of varying thickness and texture overlies both formations.

Soils reflect the normal influence of such environmental factors as elevation. exposure, vegetation, and position, as well as localized influences from clay beds or ash layers 


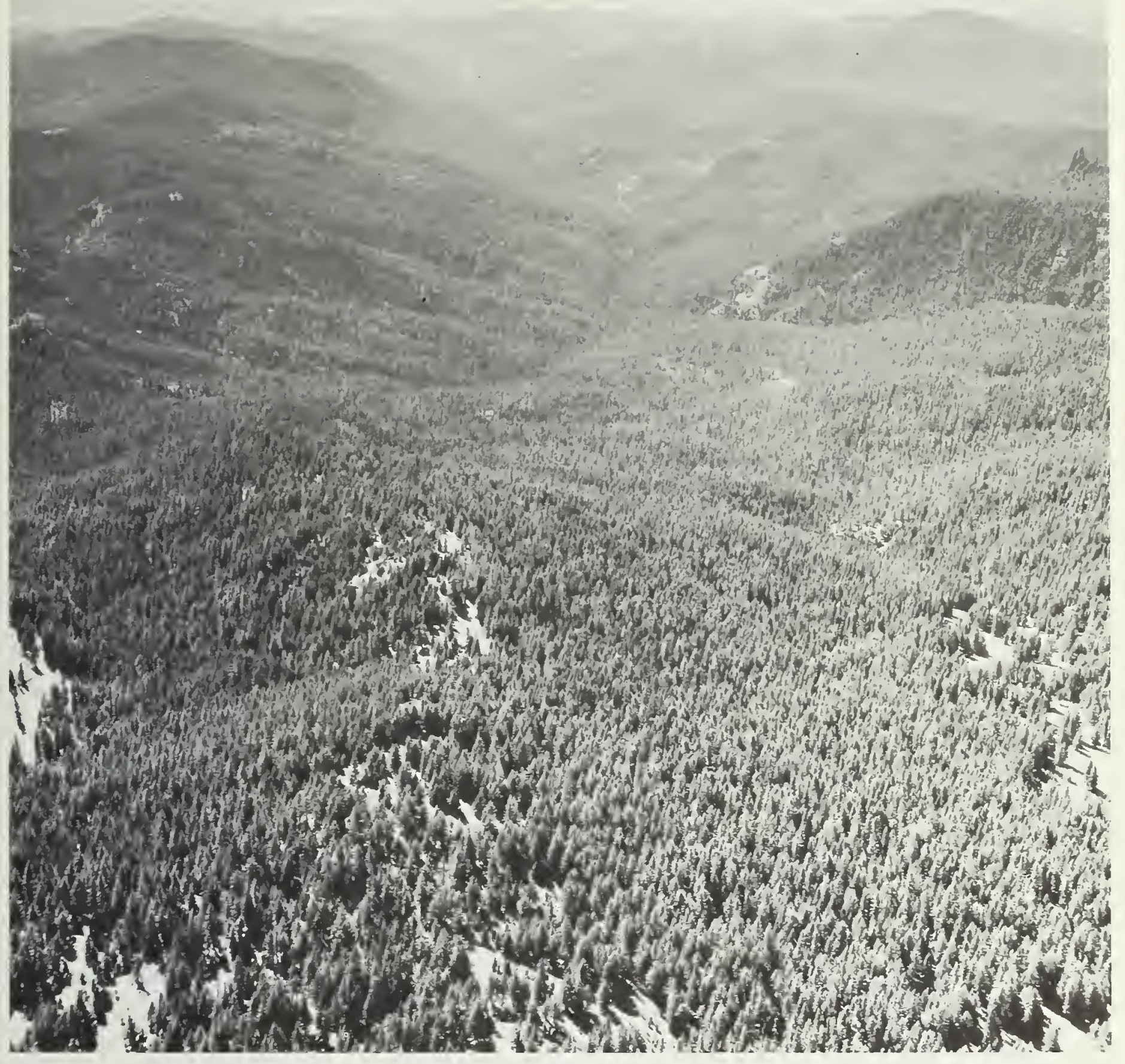

Figure 1.--Downstream view of Mill Creek, tributary to Ochoco Creek. 
found in the Clarno Formation. Most of the lower elevations are characterized by shallow soils on relatively steep slopes with occasional large rock outcrops. Deep, gravelly, medium-textured soils are found in the valley fill and narrow flood plain positions in major stream systems. Deposits of strong, medium-textured soils are found on alluvial fans that issue from side drainages and overlap the valley fill. At middle elevations, slopes become more complex and give rise to a variety of landforms including benches, valley fills, hummocky slump areas, and moderately steep colluvial slopes. Small areas of medium- to fine-textured valley fills are interspersed throughout the upper reaches.

Climate approximates Köppen's cool, snow-forest type (8) characterized by abundant sunshine, high evaporation, and wide daily and monthly temperature ranges. Mean annual temperature is $43^{\circ} \mathrm{F}$. The coldest and warmest months, respectively, are January when temperatures frequently fall below $0^{\circ} \mathrm{F}$. and July when temperatures occasionally exceed $100^{\circ} \mathrm{F}$. Freezing can occur during any month, but mean frost-free season is about 60 days near 3,000 feet elevation. Frequently, under summer conditions, humidity will drop to 10 percent during the day. With 60 percent or more of possible sunshine, potential evaporation exceeds 36 inches annually.

Mean annual precipitation for the watershed is about 25 inches, ranging from 10 inches at lower elevations to nearly 50 inches in the highest reaches. Most precipitation falls during the October-June cool season, with about 50 percent occurring as snowfall. Mean monthly precipitation and air temperature at selected stations are summarized in table 1.

Approximately 75 percent of the drainage has forest cover consisting primarily of a ponderosa pine type (fig. 2), with minor amounts of associated species (Douglas-fir, white fir, and western larch) and lodgepole pine. A small amount of alpine fir is found at the highest elevation. Most of the mature forest types have an understory of young trees varying in density from a few to over 10,000 stems per acre.
An herbaceous ground cover composed mainly of grasses and sedges occurs under most timber canopies. Deep duff and litter are found only under very dense firs.

Nonforest types make up the remaining 25 percent. Sagebrush (Artemisia tridentata) is the dominant cover in scattered locations at the highest elevations, and juniper (Juniperus occidentalis) is prevalent at the lower elevations (5). Meadows, pastures, and irrigated farmlands occupy the valley fills.

\section{Land Use History}

Ochoco Reservoir, with a capacity of 47,500 acre-feet, was constructed primarily for irrigation purposes in 1920 . The drainage area is 189,000 acres, of which 106,000 acres are administered by the Forest Service and 83,000 acres are in private ownership. Ochoco, Mill, and Marks Creeks are the major streams feeding the reservoir.

There are 52 established water rights, some dating back to the late 1800's, for irrigation of slightly more than 3,400 acres of land above the reservoir. ${ }^{1}$ This acreage has remained essentially unchanged for many years, although rates and methods of water application may have varied among different landowners. The main irrigated crops are pasture, hay, and some small grain. The normal irrigation season, from April through August, requires about 4 acre-feet of water per acre.

There are no natural storage lakes in Ochoco Creek. Walton Lake, a manmade pond of about 20 surface acres near the headwaters, reached its present stage in 1958. Annual water retention to offset pond evaporation amounts to about 50 acre-feet.

One of the earliest uses of the watershed was mining for gold and cinnabar. Placer and hard-rock gold mining started around 1855, but mining operations since that time have been sporadic. About $\$ 80,000$ in gold was produced (6). There has been no recent gold mining activity. Cinnabar was discovered in 1899 in the vicinity of Lookout Mountain.

\footnotetext{
${ }^{1}$ Personal communication with Mr. Joe Cox, local watermaster for Oregon State Engineer's Office, June 23, 1969.
} 
Table 1.--Mean monthly precipitation and air temperature, Ochoco Creek Station

\begin{tabular}{|c|c|c|c|c|c|c|}
\hline \multirow[b]{2}{*}{ Month } & \multicolumn{4}{|c|}{ Precipitation } & \multicolumn{2}{|c|}{ Mean air temperature } \\
\hline & Prineville & $\begin{array}{c}\text { Ochoco } \\
\text { Dam }\end{array}$ & $\begin{array}{l}\text { Ochoco } \\
\text { Ranger } \\
\text { Station }\end{array}$ & $\begin{array}{c}\text { Marks Creek } \\
\text { Guard } \\
\text { Station }\end{array}$ & Prineville & $\begin{array}{l}\text { Ochoco } \\
\text { Ranger } \\
\text { Station }\end{array}$ \\
\hline & \multicolumn{4}{|c|}{-Inches - - - - - . . - - } & \multicolumn{2}{|c|}{ - -Degrees Fahrenheit - } \\
\hline October & 0.78 & 0.79 & 1.65 & 1.57 & 48.1 & 45.5 \\
\hline November & 1.10 & 1.14 & 2.48 & 3.77 & 39.7 & 34.4 \\
\hline December & 1.04 & 1.27 & 2.75 & 3.75 & 33.3 & 28.7 \\
\hline January & .99 & 1.12 & 2.19 & 3.10 & 31.0 & 24.3 \\
\hline February & .84 & .85 & 1.75 & 2.20 & 35.5 & 29.5 \\
\hline March & .66 & .84 & 1.60 & 2.49 & 40.0 & 34.4 \\
\hline April & .70 & .65 & 1.31 & 1.88 & 46.0 & 41.6 \\
\hline May & 1.09 & 1.47 & 1.71 & 1.76 & 52.2 & 48.6 \\
\hline June & .99 & 1.00 & 1.68 & 1.46 & 57.8 & 53.8 \\
\hline July & .30 & .31 & .58 & .78 & 64.5 & 61.4 \\
\hline August & .31 & .46 & .60 & .77 & 62.6 & 59.7 \\
\hline September & .57 & .40 & .75 & .73 & 56.0 & 55.2 \\
\hline Annual & 9.37 & 10.30 & 19.05 & 24.26 & 47.2 & 43.1 \\
\hline
\end{tabular}

NOTE: Elevation in feet is as follows--Prineville, 2,868; Ochoco Dam, 3,057; Ochoco Ranger Station, 3,979; Marks Creek Guard Station, 4,600.

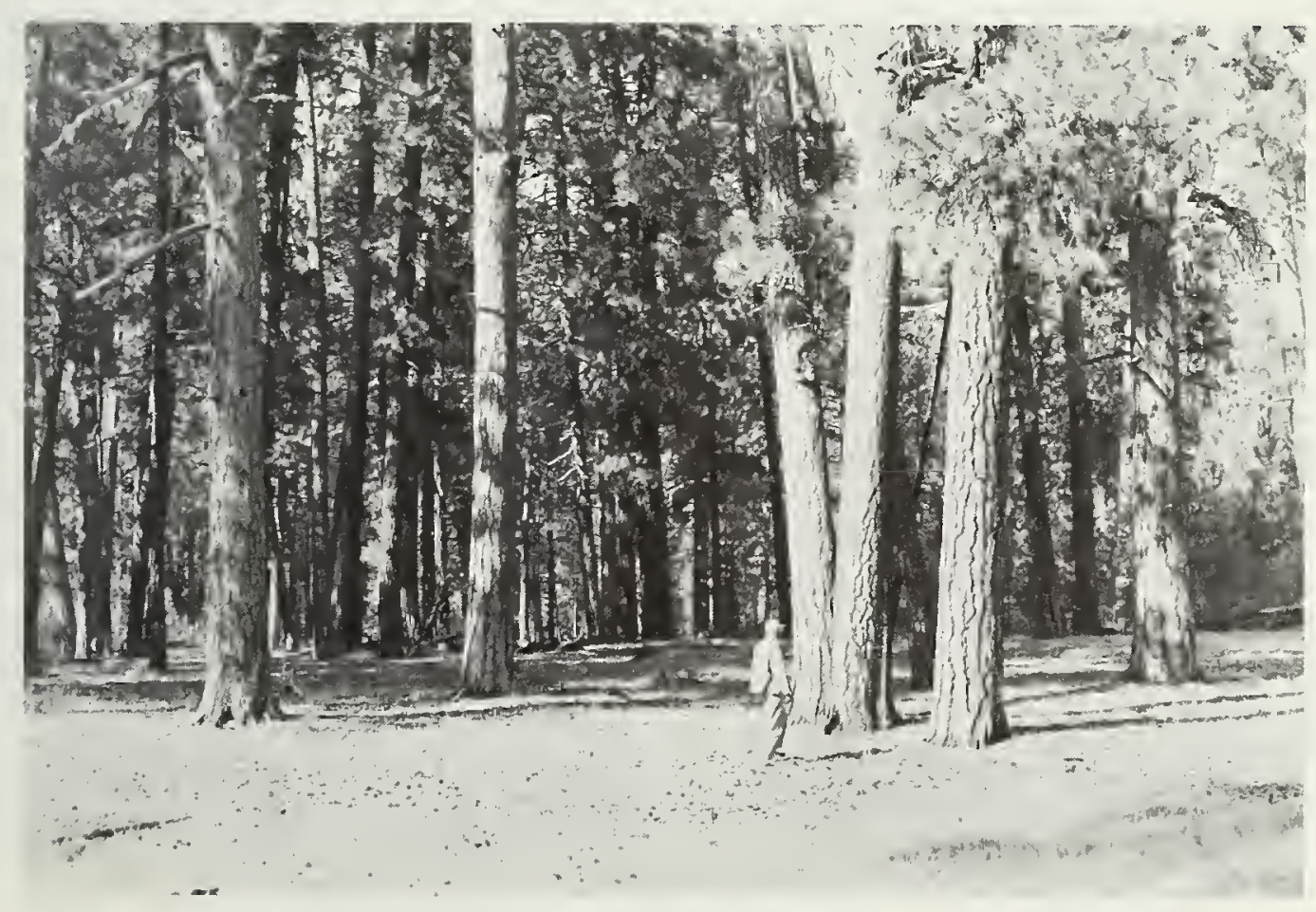

Figure 2.--Mature ponderosa pine typical of many stands on Ochoco Creek. 
Mining since that time has been sporadic with some activity as recently as the late 1950's and early 1960's (3).

The earliest cinnabar mining was underground, but the more recent technique has been open pit mining. An area of about 20 acres of open strip mining work exists in the Lookout Mountain vicinity. Otherwise, there have been no significant land disturbances, clearings, or water use for mining since the construction of Ochoco Reservoir in 1920.

There has been recent prospecting for agates, jasper, and other semiprecious stones at scattered locations throughout the watershed. No significant land disturbances have resulted from this activity.

Grazing by cattle and sheep was another early use of the area. Unregulated grazing of large numbers was a common practice in the late 1800's and early 1900's. However, grazing records on National Forest land show grazing use by cattle or sheep to be quite stable since 1924, annually averaging about 933 and 3,100 animals, respectively. Normal season of use is from about June 1 to mid-September. Table 2 shows the permitted numbers of grazing stock on National Forest and certain private lands.

A resident mule deer population was estimated at 1,500 animals through 1950 and 5,000 in 1964. The watershed also supports a small, unestimated number of Rocky Mountain elk. Hunting is allowed and is one of the major recreational uses.

Other recreational use in the watershed is quite diversified. Fishing, "rock-hounding," camping, picnicking, sightseeing, hiking, and harvesting of forest products for pleasure are permitted and dispersed throughout the basin. Concentrated recreational use takes place mainly at Walton Lake Campground, Wildcat Campground, Ochoco Summit Campground, and White Rock Springs where formal facilities are established. Ochoco Reservoir is a very popular area for waterbased recreation. Over 121,000 day visitors and 7,100 overnight campers used the facilities at Ochoco Lake State Park in 1967.

Timber harvesting, the major land use on Ochoco Creek, had a tentative beginning in the mid-1800's when early settlers cleared lands along the stream bottoms of Ochoco,
Marks, and Mill Creeks for farming. However, commercial harvest of timber did not start until about 1938 and then was principally limited to private land in the lower reaches of the watershed. From 1938 through 1945, almost 150 million board feet of timber was removed from about 25,000 acres of private land. This was a heavy cut, intended to remove 75 percent of the standing volume, yielding 2,900 to 7,700 board feet per acre. Beginning in 1947, cutting practice on private land became one of sanitation salvage, generally relogging to remove about 1,900 board feet per acre.

Commercial timber harvesting on National Forest land did not begin until 1942. By 1950 , more than 100 million board feet of timber had been removed from 14,000 acres. Per-acre cut, designed to remove 65 percent of merchantable volume, ranged from 3,500 to 12,000 board feet. Since 1950, large areas have been salvage logged of high risk timber, but generally small per-acre volumes are removed. This salvage operation has relogged much of the cutover land.

In total, over 400 million board feet of timber was harvested from the Ochoco Reservoir watershed between 1938 and 1965. Cutting on both private and Federal lands has been concentrated in the mature ponderosa pine type. As data on volumes removed per acre indicate, cutting practices have varied from essentially complete removal of mature overstory to a very selective removal of scattered trees throughout the stand (fig. 3). Timber volumes removed from the watershed are summarized in table 3 .

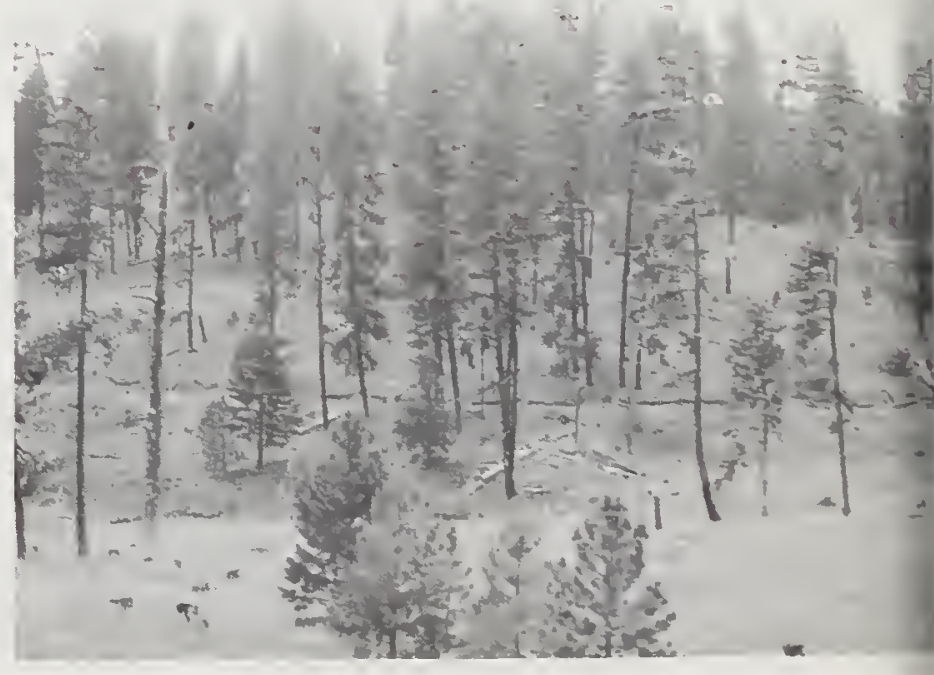

Figure 3.--Mature ponderosa pine stand after loggin 
Table 2.--Grazing record in Ochoco area, 1924-65

(Animal months ${ }^{1}$ )

\begin{tabular}{|c|c|c|c|c|c|}
\hline Year & Cattle & Sheep & Year & Cattle & Sheep \\
\hline 1924 & 4,442 & -- & 1948 & 3,690 & 11,330 \\
\hline 1929 & 3,800 & 1,188 & 1949 & 3,557 & 12,748 \\
\hline 1930 & 3,700 & 6,500 & 1950 & 3,537 & 12,079 \\
\hline 1931 & 3,600 & 6,500 & 1951 & 3,589 & 12,553 \\
\hline 1932 & 3,500 & 6,500 & 1952 & 3,557 & 14,653 \\
\hline 1933 & 3,400 & 6,500 & 1953 & 3,557 & 14,509 \\
\hline 1934 & 3,300 & 6,500 & 1954 & 3,557 & 13,709 \\
\hline 1935 & 3,200 & 17,834 & 1955 & 3,557 & 14,013 \\
\hline 1936 & 3,100 & 6,500 & 1956 & 3,644 & 14,810 \\
\hline 1937 & 1,200 & 6,500 & 1957 & 3,644 & 14,236 \\
\hline 1938 & 2,897 & 6,500 & 1958 & 3,661 & 13,345 \\
\hline 1939 & 2,560 & 6,500 & 1959 & 3,679 & 10,635 \\
\hline 1940 & 2,392 & 19,413 & 1960 & 3,516 & 15,380 \\
\hline 1941 & 2,461 & 9,658 & 1961 & 3,177 & 14,835 \\
\hline 1942 & 2,435 & 9,265 & 1962 & 3,278 & 10,105 \\
\hline 1943 & 2,249 & 9,265 & 1963 & 3,466 & 9,571 \\
\hline 1944 & 1,985 & 9,265 & 1964 & 3,624 & 14,995 \\
\hline 1945 & 2,050 & 10,974 & 1965 & 4,192 & 10,662 \\
\hline 1946 & 3,690 & -- & Total & 124,133 & 379,530 \\
\hline 1947 & 3,690 & -- & Average & 3,267 & 10,844 \\
\hline
\end{tabular}

${ }^{1}$ Animal month = one mature cow with calf or one ewe with lamb for a month's tenure.

Because cutover areas either supported advance reproduction initially or reserve stands ensured regeneration, second-growth stands contained maximum numbers of vigorous stems (fig. 4). Beginning in 1955 on some of the areas first logged, a precommercial thinning program was initiated in dense ponderosa pine stands ranging from 2 to 8 inches in diameter. The thinnings, designed on the bases of site index and size class, have resulted in spacings of 10 to 14 feet between crop trees. A total of 1,410 acres were treated in this manner during the period 1955-65.

There are nearly 300 miles of roads, varying from two-lane asphalt highways to narrow, unsurfaced work roads in the watershed. Most, however, are rock-surfaced access roads (fig. 5) progressively built in connection with timber harvesting. It is estimated that these roads comprise a total of 500 to 600 acres of bare surface. 
Table 3.--Annual timber harvest record, Ochoco Creek, 1938-65

\begin{tabular}{|c|c|c|c|c|c|c|}
\hline \multirow{2}{*}{ Year } & \multicolumn{2}{|c|}{ Cut Volume } & \multicolumn{2}{|c|}{ Area logged } & \multicolumn{2}{|c|}{ Average volume cut per acre } \\
\hline & Private $^{1}$ & $\begin{array}{l}\text { Forest } \\
\text { Service }\end{array}$ & Private $^{1}$ & $\begin{array}{c}\text { Forest } \\
\text { Service }\end{array}$ & Private $^{1}$ & $\begin{array}{l}\text { Forest } \\
\text { Service }\end{array}$ \\
\hline & \multicolumn{2}{|c|}{ - - Thousand board feet- } & \multicolumn{2}{|c|}{.......Acres ..... } & \multicolumn{2}{|c|}{... . . B Board feet . . . . . } \\
\hline 1938 & 18,500 & 0 & 2,400 & 0 & 7,700 & -. \\
\hline 1939 & 18,500 & 0 & 2,400 & 0 & 7,700 & -- \\
\hline 1940 & 18,500 & 0 & 2,400 & 0 & 7,700 & -- \\
\hline 1941 & 18,500 & 0 & 2,400 & 0 & 7,700 & - \\
\hline 1942 & 18,500 & 2,711 & 3,240 & 220 & 5,700 & 12,300 \\
\hline 1943 & 18,500 & 250 & 6,427 & 21 & 2,900 & 11,900 \\
\hline 1944 & 18,500 & 708 & 3,593 & 59 & 5,140 & 12,000 \\
\hline 1945 & 18,500 & 727 & 2,604 & 61 & 7,100 & 11,900 \\
\hline 1946 & 2,000 & 7,964 & 453 & 664 & 4,410 & 12,000 \\
\hline 1947 & 4,800 & 13,916 & 2,500 & 4,011 & 1,900 & 3,500 \\
\hline 1948 & 4,800 & 12,460 & 2,500 & 1,577 & 1,900 & 7,900 \\
\hline 1949 & 4,800 & 35,421 & 2,500 & 4,800 & 1,900 & 7,400 \\
\hline 1950 & 4,800 & 27,228 & 2,500 & 3,230 & 1,900 & 8,400 \\
\hline 1951 & 4,800 & 512 & 2,500 & 50 & 1,900 & 10,000 \\
\hline 1952 & 4,800 & 2,803 & 2,500 & 9,080 & 1,900 & 300 \\
\hline 1953 & 4,800 & 531 & 2,500 & 106 & 1,900 & 5,000 \\
\hline 1954 & 4,800 & 3,661 & 2,500 & 8,500 & 1,900 & 430 \\
\hline 1955 & 4,800 & 0 & 2,500 & 0 & 1,900 & - \\
\hline 1956 & 4,800 & 488 & 2,500 & 6,100 & 1,900 & 80 \\
\hline 1957 & 4,800 & 1,849 & 2,500 & 217 & 1,900 & 8,500 \\
\hline 1958 & 4,800 & 11,544 & 2,500 & 17,240 & 1,900 & 660 \\
\hline 1959 & 4,800 & 4,349 & 2,500 & 765 & 1,900 & 5,700 \\
\hline 1960 & 4,800 & 9,384 & 2,500 & 13,795 & 1,900 & 680 \\
\hline 1961 & 4,800 & 3,524 & 2,500 & 7,160 & 1,900 & 490 \\
\hline 1962 & 4,800 & 462 & 2,500 & 400 & 1,900 & 1,150 \\
\hline 1963 & 4,800 & 31,170 & 2,500 & 10,628 & 1,900 & 2,900 \\
\hline 1.964 & 4,800 & 20,805 & 2,500 & 8,647 & 1,900 & 2,400 \\
\hline 1965 & 4,800 & 2,538 & 2,500 & 3,035 & 1,900 & 830 \\
\hline Total & 241,200 & 195,004 & 73,417 & 100,366 & 3,290 & 5,270 \\
\hline
\end{tabular}

${ }^{1}$ Annual data derived by averaging. 


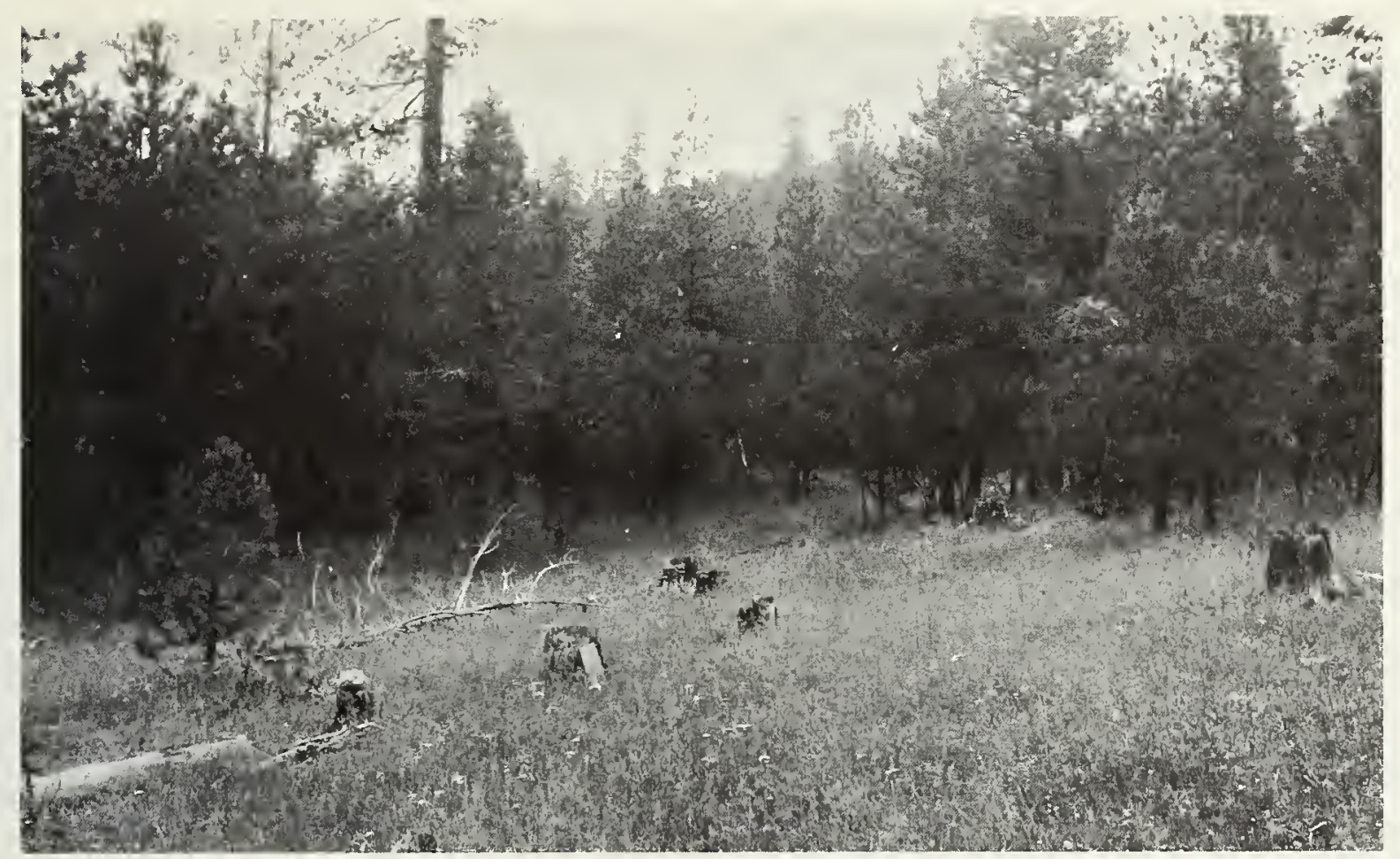

Figure 4.--Dense second-growth ponderosa pine.

There were no serious forest fires in the watershed during 1920-65. Most involved a quarter of an acre or less, and the largest recorded fire, only 85 acres. A review of the fire records shows damage has generally been minor. Fire history of the watershed is summarized below.

$\begin{array}{cccc}\frac{\text { Period }}{1920-29} & \begin{array}{c}\text { Total } \\ \text { number of fires }\end{array} & & \begin{array}{c}\text { Total acres } \\ \text { burned }\end{array} \\ 1930-39 & 119 & & 330 \\ 1940-49 & 119 & 119 \\ 1950-59 & 152 & 200 \\ 1960-65 & 52 & 19 \\ \text { Total } & \underline{84} & & 18 \\ & 526 & 686\end{array}$

\section{Hydrologic Relations}

The principal method of relating available precipitation and streamflow data for Ochoco Creek was the double-mass curve. In application, the graph of the cumulative data of one sequential variable plotted against the cumulative data of a related sequential variable is a straight line if the relation between the variables is fixed. If the relation changes

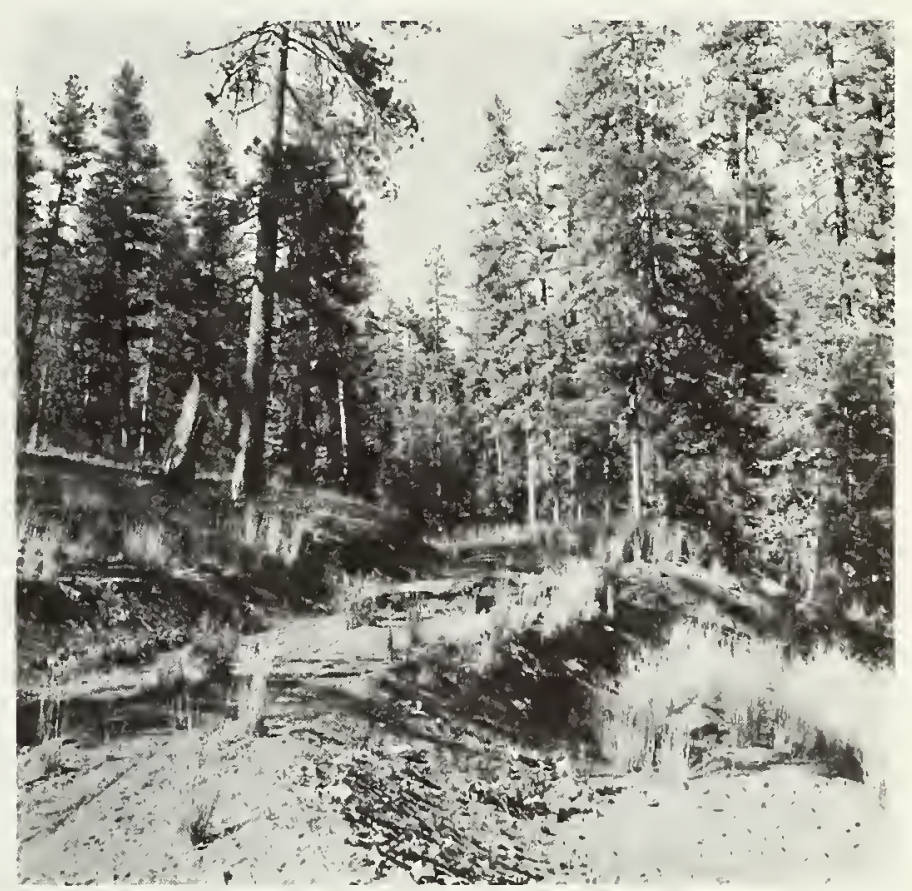

Figure 5.--Typical logging spur road. Disturbed areas are seeded to grasses. 
during the plotted sequence, due either to a change in data collecting techniques or to some physical change, a break or change in slope will appear. Statistical tests for significance of apparent slope breaks can be made (16).

\section{Precipitation-Runoff Relations}

Precipitation stations within or closely adjacent to the Ochoco Creek basin, with periods of records long enough to be useful in analysis, are at Prineville, Oreg. (1897 to present) and Ochoco Ranger Station (1936 to present). Annual precipitation amounts recorded at these locations appear in table 4.

Ochoco Reservoir, essentially containing the outflow of Ochoco Creek, has been in continuous operation by the Ochoco Irrigation District since 1920. Records of reservoir level, flow in irrigation feed canals, and flow of Ochoco Creek below the reservoir are convertible to reservoir inflow. Annual inflows for water years ${ }^{2} 1922-65$ are shown in table 4.

The first step in analysis of Ochoco Creek hydrologic data was to check the consistency of precipitation records at Prineville and Ochoco Ranger Stations. A double-mass plot (fig. 6) of the annual precipitation report of these two stations shows a distinct slope break at the water year 1957. The double-mass plotting of each of these stations individually against a third station, nearby but outside the Ochoco drainage, determined that the slope break was attributable to a change at the Prineville station. Subsequent inquiry disclosed that about 1956 the Prineville station was moved nearly 3 miles to a new Weather Bureau cooperator location. The curve in figure 6 was used to adjust Prineville precipitation data subsequent to 1956 to make it consistent with prior records.

Precipitation at both stations and Ochoco Reservoir inflow were then related by use of

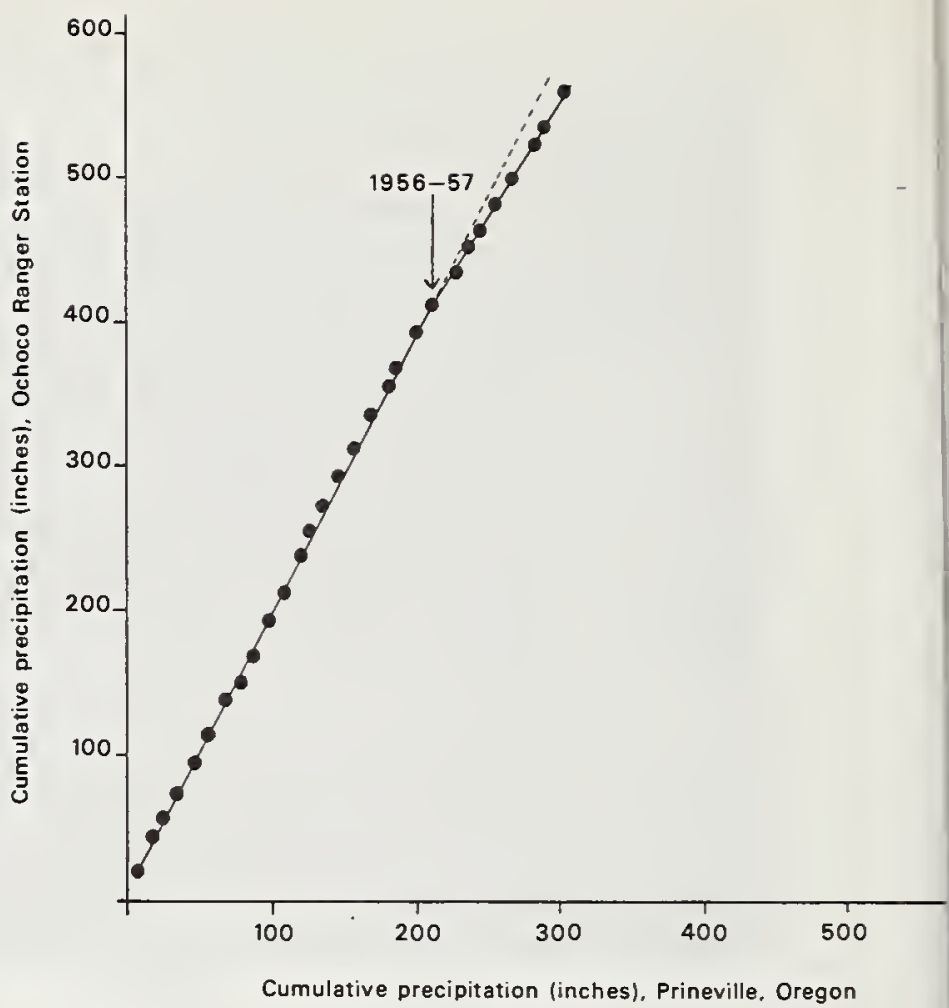

Figure 6.--Double-mass curve of precipitation data.

double-mass plots (figs. 7 and 8). Because the relation between precipitation and streamflow is seldom a constant ratio, these curves are not intended for analysis. Rather, they are useful only if we look at trends or possible changes in precipitation-runoff relations for further analysis.

Figure 7, the double-mass plot of Prineville precipitation and Ochoco Reservoir inflow, shows two distinct slope breaks which suggest changes in precipitationstreamflow relations. The first is a sharp break at water year 1942. The second and less distinct break occurred at water year 1956.

Figure 8, relating precipitation at Ochoco Ranger Station to reservoir inflow, also shows a distinct break at water year 1942 and a less distinct break at water year 1957.

\footnotetext{
${ }^{2}$ In this report, a water year begins October 1 and ends September 30. Numerical designation is the calendar year in which the water year ends.
} 
Table 4.--Annual precipitation amounts, Prineville and Ochoco Ranger Station, and Ochoco Reservoir inflow, 1922-65

(Inches)

\begin{tabular}{|c|c|c|c|}
\hline \multirow{2}{*}{ Water year } & \multicolumn{2}{|c|}{ Precipitation } & \multirow{2}{*}{$\begin{array}{c}\text { Inflow, } \\
\text { Ochoco Reservoir }\end{array}$} \\
\hline & Prineville & Ochoco Ranger Station & \\
\hline 1922 & 8.63 & -- & 2.84 \\
\hline 1923 & 11.85 & -- & 2.57 \\
\hline 1924 & 7.98 & -- & 0.89 \\
\hline 1925 & 11.48 & -- & 2.89 \\
\hline 1926 & 7.59 & -- & .87 \\
\hline 1927 & 8.38 & -- & 3.24 \\
\hline 1928 & 6.98 & -- & 2.83 \\
\hline 1929 & 4.49 & -- & .46 \\
\hline 1930 & 8.60 & -- & .28 \\
\hline 1931 & 6.84 & -- & .40 \\
\hline 1932 & 7.75 & -- & 2.37 \\
\hline 1933 & 7.07 & -- & 1.45 \\
\hline 1934 & 9.11 & -- & .17 \\
\hline 1935 & 8.26 & -- & 1.15 \\
\hline 1936 & 11.13 & -- & 1.61 \\
\hline 1937 & 8.98 & 20.50 & 1.72 \\
\hline 1938 & 10.31 & 22.96 & 3.55 \\
\hline 1939 & 4.98 & 14.29 & .83 \\
\hline 1940 & 10.76 & 15.17 & 1.59 \\
\hline 1941 & 11.16 & 21.02 & 1.21 \\
\hline 1942 & 11.23 & 18.53 & 3.24 \\
\hline 1943 & 12.31 & 25.39 & 6.29 \\
\hline 1944 & 10.31 & 12.32 & .70 \\
\hline 1945 & 9.19 & 18.94 & 2.62 \\
\hline 1946 & 9.90 & 23.15 & 6.77 \\
\hline 1947 & 9.34 & 19.75 & 1.42 \\
\hline 1948 & 12.55 & ${ }^{1} 26.16$ & 5.88 \\
\hline 1949 & 5.91 & ${ }^{1} 15.40$ & 4.15 \\
\hline 1950 & 8.15 & 17.66 & ${ }^{1} 4.26$ \\
\hline 1951 & 11.08 & ${ }^{1} 20.70$ & 5.93 \\
\hline 1952 & 12.00 & 20.12 & 4.57 \\
\hline 1953 & 11.89 & 23.91 & 4.12 \\
\hline 1954 & 11.20 & 19.21 & $3.2 \overline{2}$ \\
\hline 1955 & 5.08 & 14.11 & 1.09 \\
\hline 1956 & 14.16 & 24.14 & 6.08 \\
\hline 1957 & 11.37 & 17.39 & ${ }^{1} 3.24$ \\
\hline 1958 & 16.28 & 25.40 & 5.46 \\
\hline 1959 & 8.11 & 14.63 & 1.15 \\
\hline 1960 & 7.72 & 13.33 & 1.44 \\
\hline 1961 & 11.82 & 17.52 & 2.37 \\
\hline 1962 & 11.84 & 18.21 & 3.39 \\
\hline 1963 & 13.73 & 20.72 & 3.18 \\
\hline 1964 & 7.69 & 14.73 & 1.46 \\
\hline 1965 & 14.68 & 24.34 & 5.77 \\
\hline
\end{tabular}

${ }^{1}$ Estimated in part. 


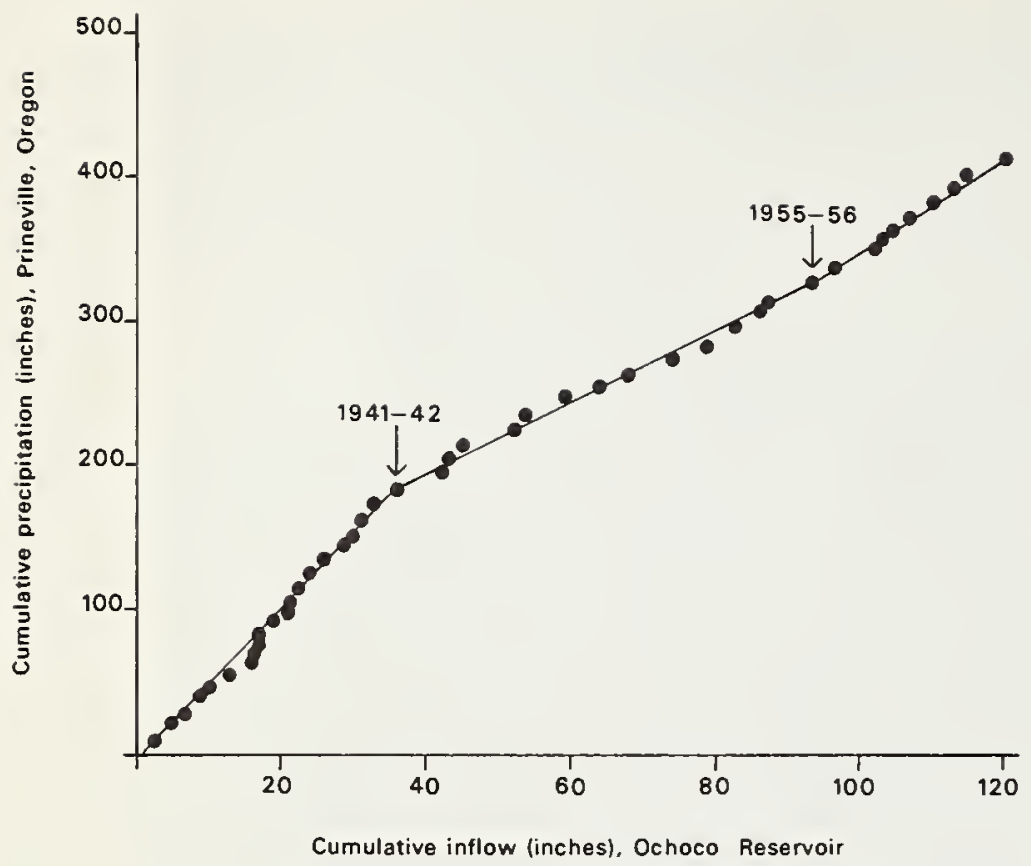

Figure 7.--Double-mass curve of precipitation and reservoir inflow.

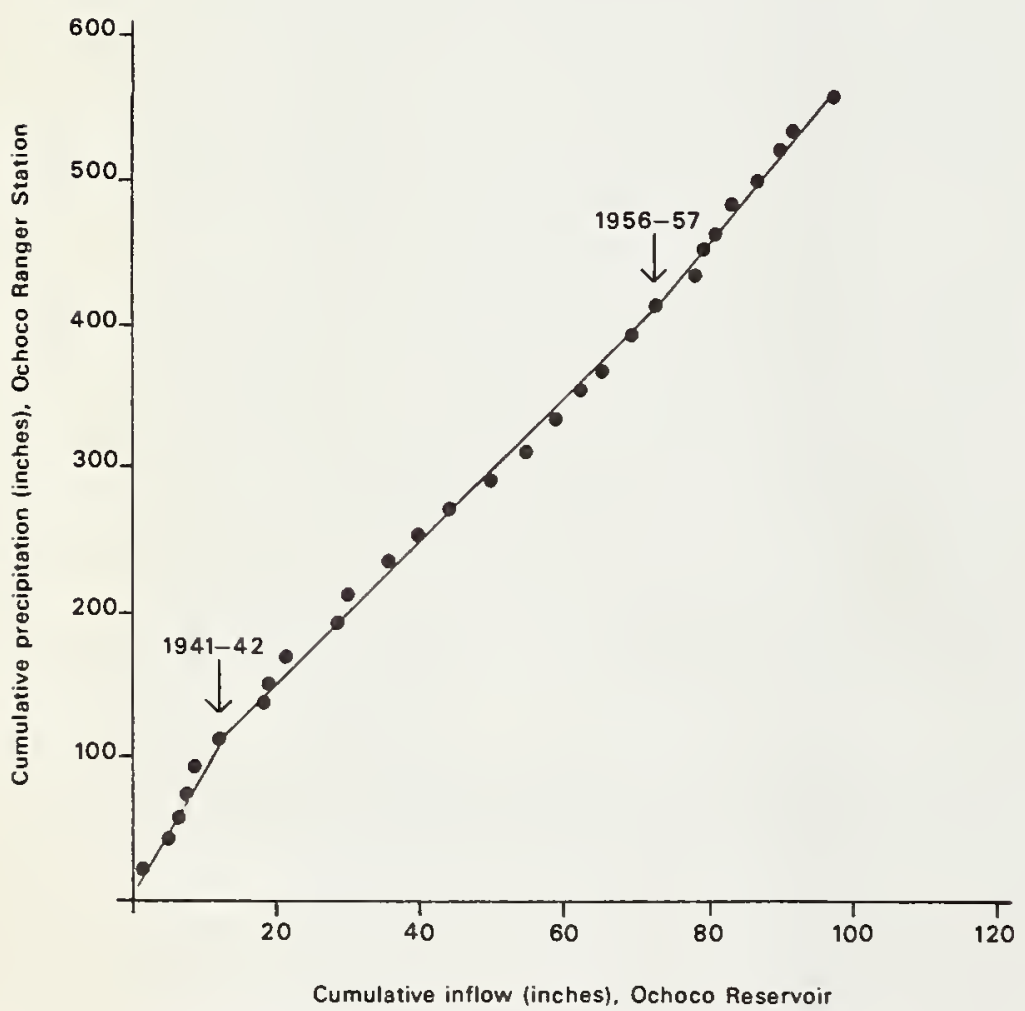

Figure 8.-Double-mass curve of precipitation and reservoir inflow.
Double-Mass Analysis

An analysis relating precipitation at Ochoco Ranger Station to Ochoco Reservoir inflow would be desirable, because that station is located near the center of the basin. However, since precipitation records prior to 1937 are not available, it became necessary to use the longer Prineville precipitation records in the analysis.

When the double-mass curve is used in an analysis of precipitation-runoff relations or streamflow trends, the cumulative measured flow should be plotted against a cumulative computed or pattern flow based on some determined precipitation-runoff relation. A variable ratio between precipitation and streamflow violates the theory of doublemass analysis.

A means for computing pattern inflow at Ochoco Reservoir was developed by relating cumulative annual precipitation at Prineville to cumulative annual reservoir inflow for water years 1922 to 1942 (see fig. 7) through a least squares fit linear regression. ${ }^{3}$ This regression equation was then used in computing cumulative pattern inflow for each water year from 1922 to 1965 .

Figure 9 is the resulting double-mass plot of computed pattern inflow against measured inflow into Ochoco Reservoir.

A number of year-to-year breaks are evident in figure 9. However, most users of double-mass curves recognize that short-term changes can be due to chance and generally choose to ignore breaks persisting for less than 5 years. Two distinct slope breaks persisting for more than 5 years are identifiable at water years 1942 and 1958 . The first, indicating increased flow during water years 1942 to 1958, represents a departure from pattern flow of +2.21 inches per year. During the period 1958 to 1965 , the departure from pattern flow amounted to +1.03 inches per year.

\footnotetext{
${ }^{3} \hat{y}=2.27+0.1826 X ; r=0.994$

where $X=$ cumulative precipitation, in inches, at Prineville, Oreg.

$\hat{v}=$ estimated cumulative inflow in inches.
} 
To determine whether the apparent slope breaks in figure 9 occurred by chance, statistical tests of significance were made by methods of covariance. The periods 1942-58 and 1958-65 were tested against the period 1921-42. Differences were found to be highly significant ${ }^{4}$ in both cases. The difference between the 1942-58 and the 1958-65 periods was found to be significant at the 95-percent confidence level.

These statistical tests show that increased streamflow subsequent to 1942 did not occur due to chance. They show further that the 1.18 inches average decrease in annual flow after 1958 is a real change.

The recognized slope breaks indicate times at which inconsistencies or changes occurred in the relation between pattern and measured flows. The difference in slopes of the lines on either side of the breaks indicates the extent of the change. With reasonable assurance that data collection methods have not changed, the need remains to identify plausible events or physical changes which coincide with slope breaks. Knowing the approximate timing of changes in streamflow relationships, one may analyze the history of Ochoco Creek for causes. However, such analysis is necessarily qualitative due to the general character of certain use data.

The possibility exists that streamflow relations changed in response to a persistent climatic change. Though annual precipitation amounts at Prineville during the period 1922-65 are essentially a normal distribution, mean annual precipitation during 1943-58 was nearly 2 inches greater than during 1922-42. However, from prediction equations developed for both periods, ${ }^{5}$ a streamflow increase of only 0.5 to 0.7 inch would be the expected result of a 2 -inch increase in annual precipitation.

\footnotetext{
${ }^{4}$ Significant at the 99-percent confidence level.

$5 \hat{y}=0.24 X-0.38 ; r=0.48$

$\hat{y}=0.36 X+0.27 ; r=0.52$

where $X=$ annual precipitation, in inches, at Prineville, Oreg.

$\hat{v}=$ estimated annual inflow, in inches, at Ochoco Reservoir.
}

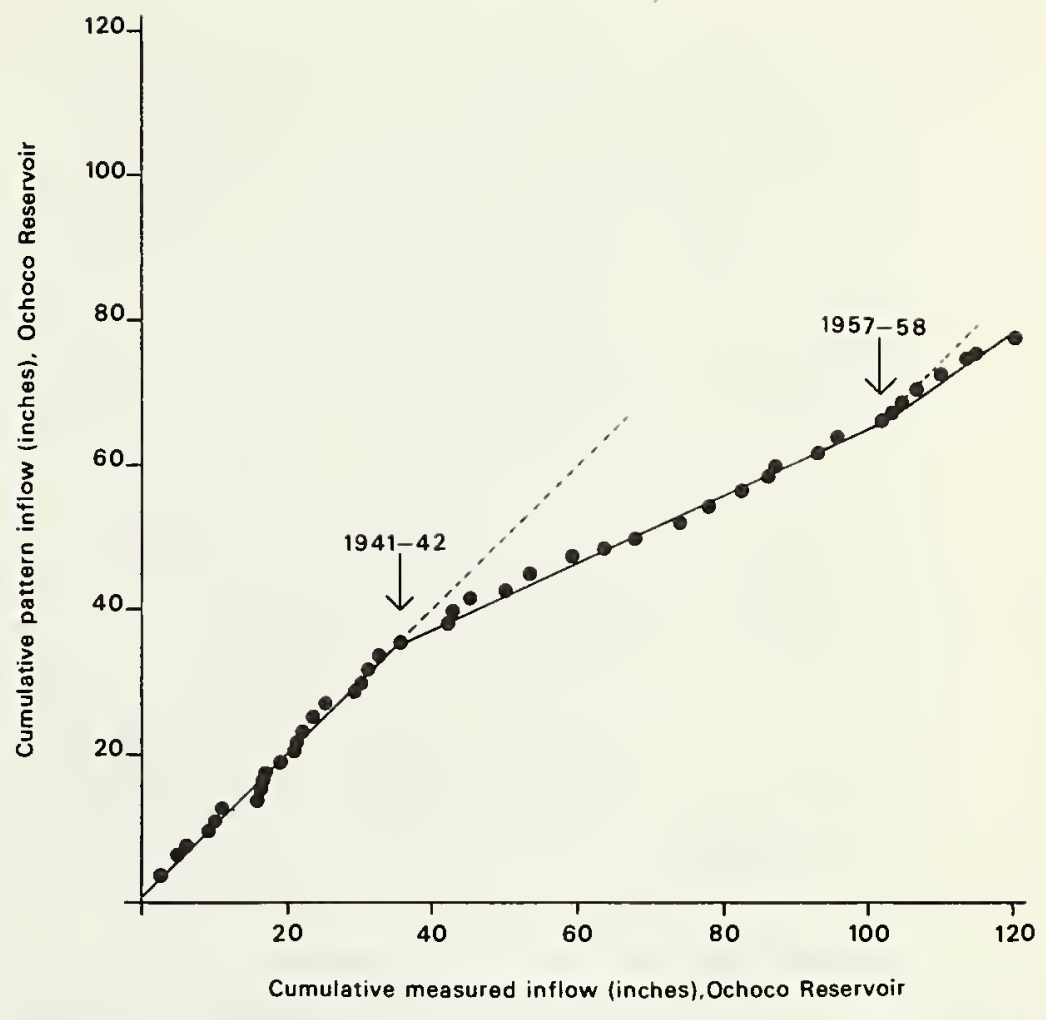

Figure 9.--Double-mass curve of measured and pattern inflow.

Certain land use activities, such as diversions for irrigation agriculture above the reservoir and for forest grazing, have been essentially stable throughout the period studied. Consequently, they provide no logical explanation for streamflow changes. Other uses, such as recreation and mining, either alter the landscape very little or occupy such minute portions of the basin that they also fail to suggest causes for major changes in hydrologic response. Similarly, fires have been but minor events in land use history.

Timber harvest is the only recorded major land use on Ochoco Creek which might conceivably result in a significant change in water yield. And intensification of timber harvest activity, beginning in 1938 and peaking in 1949 , is approximately coincident with the first break identified in the double-mass curve (fig. 9). 
The slope break occurring about water year 1958, manifested as a streamflow decrease of 1.18 inches per year, does not coincide with any particular recorded activity. It may represent a trend toward original flow values, similar to trends observed in water yield experiments dealing with forest cutting. Commercial timber harvest during 1938-49 removed high per-acre volumes from mature stands. Dense second-growth stands resulting from this heavy cutting now fully occupy most of these sites. Since 1951, timber harvesting generally has been on a sanitation salvage basis removing low peracre volumes. These two factors - full stocking of older cutover by dense second growth, and general reduction of timber harvest - could conceivably combine in higher transpiration draft, thus decreasing water yield.

\section{Sedimentation}

There are no formal records of sedimentation in Ochoco Reservoir. The manager of the Ochoco Irrigation District, a longtime resident of the area, believes that in the past 45 years the reservoir capacity has been reduced 250 to 500 acre-feet by sediment. He further believes that most of this sediment is the result of two major DecemberJanuary floods in 1945-46 and 1964-65. No reservoir management or irrigation problems have resulted from either suspended or deposited sediments. ${ }^{6}$

\section{SUMMARY}

The prosperity of the West greatly depends on adequacy of water supplies. Though much water use is at considerable distance from the forest, forest lands are intimately related to western irrigation in that they are the origin of perhaps 85 percent of the water. In central Oregon, water will probably fix the upper limits of population and living standards.

In this case study, the hydrologic performance of a 295-square mile drainage in central Oregon was compared with the land use history for the period 1921-65. Two distinct changes in streamflow regimen were identified. The first, beginning about water year 1942, was an increase of 2.21 inches in average annual yield. The timing of this increase is approximately coincident with the onset of timber harvesting activity in the basin. The second change was a decrease of 1.18 inches in average water yield beginning about 1958. This change could possibly be related to the full stocking of cutover lands by dense, second-growth stands and a general reduction of timber harvest activity.

Though more sensitive, refined tests of the influence of timber harvest on water yield are needed for stands east of the Cascade Range, the analyses in this report show that accepted management practices for vegetative types found on Ochoco Creek have favored water yields.

${ }^{6}$ Personal communication, Mr. LaSelle E. Coles, Ochoco Irrigation District Manager, Prineville, Oreg., June 23, 1969. 


\section{LITERATURE CITED}

1. Bates, C. G. 1934. Discussion of "Forests and streamflow," by W. G. Hoyt and H. C. Troxell. Amer. Soc. Civil Eng. Trans. 99: 31-36.

2. Bates, C. G., and Henry, A. J. 1928. Forest and stream flow experiment at Wagon Wheel Gap, Colorado. Mon. Weather Rev. Suppl. 30, 79 pp., illus.

3. Brooks, Howard C. 1963. Quicksilver in Oregon. Oreg. State Dep. Geol. \& Mineral Ind. Bull. 55, 223 pp., illus.

4. Dortignac, Edward J., and Beattie, Byron. 1965. Using representative watersheds to manage forest and range lands for improved water yield. Int. Ass. Sci. Hydrol. 2(66): 480-488.

5. Franklin, Jerry F., and Dyrness, C. T. 1969. Vegetation of Oregon \& Washington. Pacific Northwest Forest \& Range Exp. Sta. USDA Forest Serv. Res. Pap. PNW-80, 216 pp., illus.

6. Gilluly, James, Reed, J. C., and Park, C. F., Jr. 1933. Some mining districts of eastern Oregon. U.S. Geol Surv. Bull. 846A, 140 pp., illus.

7. Goodell, Bertram C. 1958. A preliminary report on the first year's effects of timber harvesting on water yield from a Colorado watershed. USDA Forest Serv. Rocky Mountain Forest Exp. Sta. Pap. 36, 12 pp.

8. Haurwitz, Bernhard, and Austin, James M. 1944. Climatology. 410 pp., illus. McGraw-Hill Book Co., Inc.

9. Hibbert, Alden R. 1967. Forest treatment effects on water yield. In International symposium on forest hydrology. Sopper, William E., and Lull, Howard W. (eds.). Pp. 527-543, illus. London, Edinburgh [etc.]: Pergamon Press, Symp. Publ. Div.

10. Hoover, M. D. 1944. Effect of removal of forest vegetation upon water yields. Amer. Geophys. Union Trans. 6: 969-975, illus.
11. Kovner, Jacob L. 1956. Evapotranspiration and water yields following forest cutting and natural regrowth. Soc. Amer. Forest. Proc., pp. 106-110, illus.

12. Oregon State Water Resources Board. 1969. Summary report of Oregon's long-range requirements for water. 15 pp., illus.

13. Phillips, K. N., Newcomb, R. C., Swenson, H. A., and Laird, L. B. 1965. Water for Oregon. U.S. Geol. Surv. WaterSupply Pap. 1649, 150 pp., illus.

14. Reinhart, K. G., Eschner, A. R., and Trimble, G. R., Jr. 1963. Effect on streamflow of four forest practices in the mountains of West Virginia. Northeastern Forest Exp. Sta. USDA Forest Serv. Res. Pap. NE-1, 79 pp.

15. Rice, R. M., and Wallis, J. R. 1962. How a logging operation can affect streamflow. Forest Ind. 89(11): 38-40, illus.

16. Searcy, James K., and Hardison, Clayton H. 1960. Double-mass curves. U.S. Geol. Surv. Water-Supply Pap. 1541-b, 66 pp., illus.

17. USDA Forest Service. 1969. Water yield improvement potentials on National Forest lands tributary to Ochoco Reservoir. Pacific Northwest Region. 52 pp., illus. 


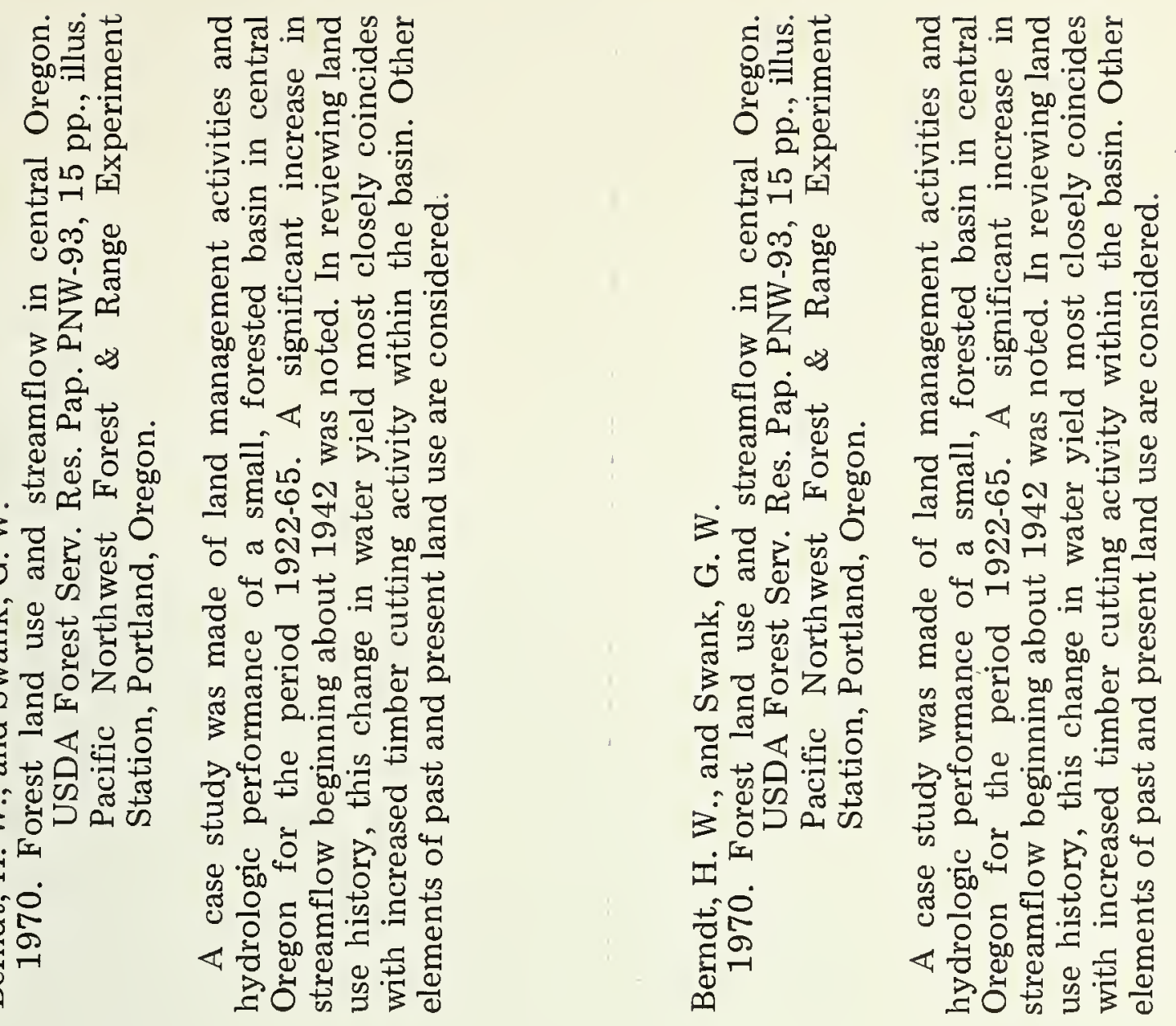
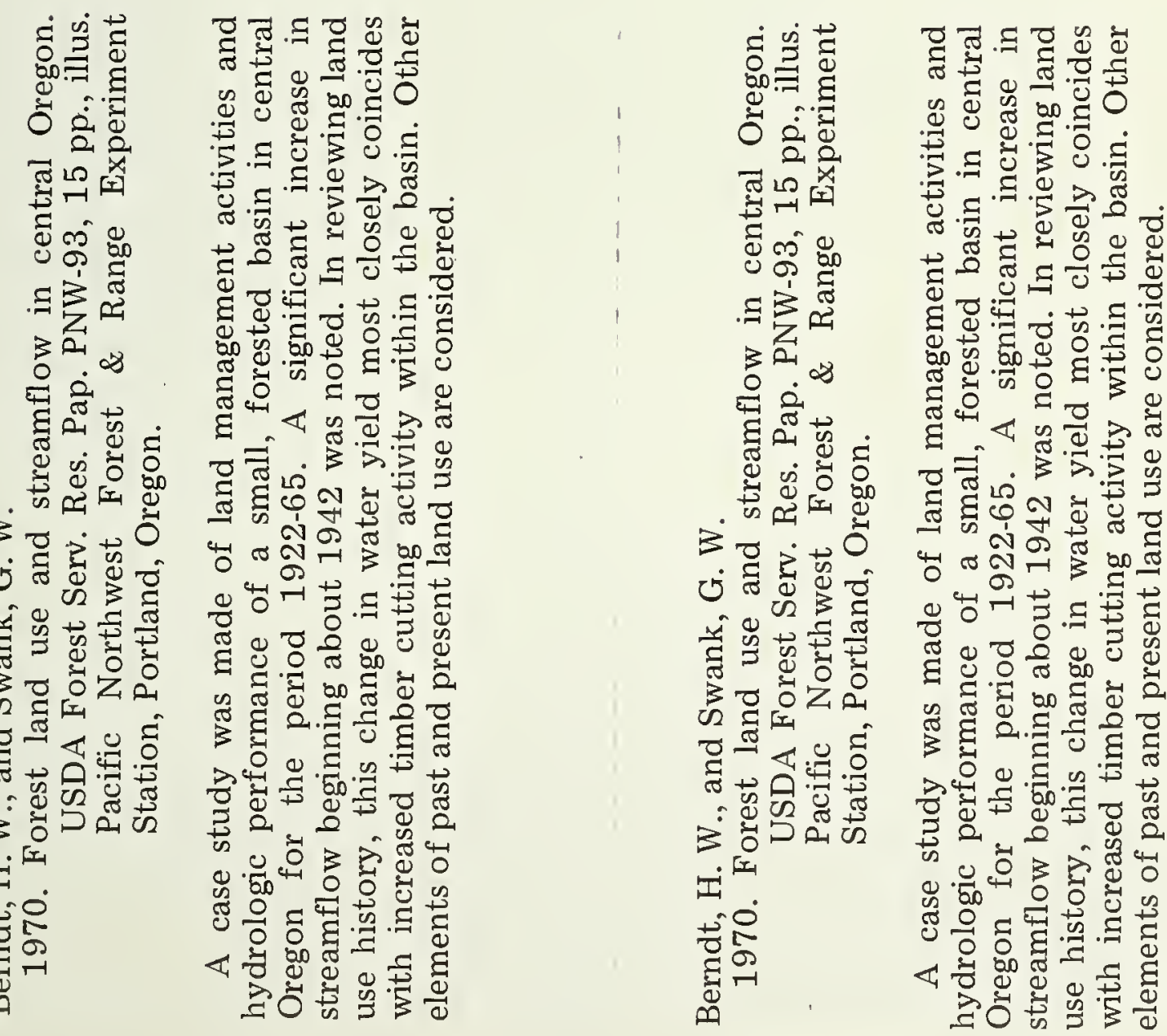

Headquarters for the PACIFIC NORTHWEST FOREST AND RANGE EXPERIMENT STATION is in Portland, Oregon. The Station's mission is to provide the scientific knowledge, technology, and alternatives for management, use, and protection of forest, range, and related environments for present and future generations. The area of research encompasses Alaska, Washington, and Oregon, with some projects including California, Hawaii, the Western States, or the Nation. Project headquarters are at:

College, Alaska Juneau, Alaska Bend, Oregon Corvallis, Oregon La Grande, Oregon
Portland, Oregon Roseburg, Oregon Olympia, Washington Seattle, Washington Wenatchee, Washington 
The FOREST SERVICE of the U.S. Department of Agriculture is dedicated to the principle of multiple use management of the Nation's forest resources for sustained yields of wood, water, forage, wildlife, and recreation. Through forestry research, cooperation with the States and private forest owners, and management of the National Forests and National Grasslands, it strives - as directed by Congress - to provide increasingly greater service to a growing Nation. 